Agro-Science Journal of Tropical Agriculture, Food, Environment and Extension Volume 20 Number 1 (January 2021) pp. $15-21$

ISSN 1119-7455

\title{
GROWTH AND YIELD OF SESAME (Sesamum indicum) AS INFLUENCED BY PLANT POPULATION DENSITY AND ORGANO-MINERAL FERTILIZER RATES
}

\author{
Oloniruha J.A., Ogundare S.K. and Olajide K. \\ Kabba College of Agriculture, Division of Agricultural Colleges, \\ Ahmadu Bello University, Kabba Campus, Kogi State, Nigeria \\ "Corresponding author's email: okolawole40@yahoo.com
}

\begin{abstract}
Sesame (Sesamum indicum L.) is an important oil-seed crop cultivated for its high nutrition and edible seeds. However, its cultivation is affected by low soil fertility, wrong choice of plant population density and time of sowing. The experiment was carried out during the 2016 and 2017 cropping seasons at the Research Site of Agronomy Section, Kabba College of Agriculture, Kabba, Kogi State, Nigeria. The experiment evaluated the influence of plant population density and organo-mineral fertilizer rates on the performance of Sesame in Kabba, Kogi State, Nigeria. The experiment was a split plot design replicated thrice. The main plot treatment was three plant population density $\left(P 1=111,111 ; \mathrm{P2}=83,333\right.$ and $\mathrm{P} 3=66,667$ plants $\left.^{-1}{ }^{-1}\right)$ and the sub-plot treatment was four organo-mineral fertilizer rates $\left(F \mathrm{~F}=0, \mathrm{F1}=500, \mathrm{F2}=1000, \mathrm{F3}=1500 \mathrm{~kg} \mathrm{ha}^{-1}\right)$. Data were collected on growth, morphological characters (plant height, number of leaves, number of branches) and yield components (number of capsules plant ${ }^{-1}, 1000$ seed weight and yield ha ${ }^{-1}$ ). The result showed that the plant at P1 produced the tallest plants throughout the period of sampling, which was closely followed by $P 2$ while P3 produced the shortest plants. Numbers of capsules plant ${ }^{-1}$ was highest in plots with P1 which was statistically the same with the number of capsules plant ${ }^{-1}$ in P2. Number of capsules plant ${ }^{-1}$ in P1 and P2 were statistically better than the plots with P3. Plots treated with rate F2 gave the highest number of capsules and also recorded the highest yield in 2016 and 2017 growth seasons. The results indicated that Sesame with closest spacing was better in terms of seed yield land ${ }^{-1}$ area while widest spacing gave the highest individual yield attributes. For economic use of land, it is concluded that plant population density at 111,111 be adopted in the production of Sesame. Best growth and yield performance of Sesame was achieved with $1500 \mathrm{~kg} \mathrm{ha}^{-1}$ of organo-mineral fertilizer and is recommended for optimum production of Sesame in the study area.
\end{abstract}

Key words: plant density, organo-mineral fertilizer, growth traits, seed yield, Sesame

\section{INTRODUCTION}

Sesame (Sesamum indicum L.) is cultivated in tropical and sub-tropical Africa for its highly nutritious and edible seeds (Iwo et al., 2002). It is cultivated in the savannah zones of Nigeria (Alegbejo et al., 2003). Sesame produce between $50-60 \%$ oil from the seeds and the oil is of excellent quality, this is due to the presence of antioxidants such as sesamol and sesaminol (Olowe and Busari, 2003). The oil is used in preparing salad, or used in making margarine, soap, paints, cosmetics, perfumes and insecticides (Babaji et al., 2005; 2006). According to Dudley et al. (2000), the oil is used in cooking and baking, food manufacture, alternative medicine and making of candy, soaps, lubricants, body massage and hair treatments, among other industrial uses.

In sesame cultivation, plant densities vary considerably, depending on the environment, production system and cultivar. Plant population density is an essential component of yield, and thus the yield of individual plant. A uniform distribution of plants per unit area is a prerequisite for yield stability (Diepenbrock, 2000). Al Barzinjy et al. (1999) reported that the number of capsules per plant, seed weight and dry matter per plant decreased as plant density increased in oilseed rape. Leach et al. (1999) also reported that plants grown at high density (150 plants $\mathrm{m}^{-2}$ ) had fewer podbearing branches per plant but produced more branches and also an increase in plant density also led to an increase in 1000 seed weight.

The performance of any crop is determined by the planting geometry which dictates the population of the plant on the field. Plant population affects the interception of sunlight by plant canopy (Board, 2001). Plant height declines with reduced plant population. Stem sections of plants that receive more light usually tend to have slower elongation (Sevgi et al., 2011).

Please cite as: Oloniruha J.A., Ogundare S.K. and Olajide K. (2021). Growth and yield of sesame (Sesamum indicum) as influenced by plant population density and organo-mineral fertilizer rates. Agro-Science, 20 (1), 15-21. DOI: https://dx.doi.org/10.4314/as.v20i1.3 
In Nigeria, the average yield of sesame obtained by farmers is $300 \mathrm{~kg} \mathrm{ha}^{-1}$ compared with $1,960 \mathrm{~kg}$ $\mathrm{ha}^{-1}$ in Venezuela, $1,083 \mathrm{~kg} \mathrm{ha}^{-1}$ in Saudi Arabia, $517 \mathrm{~kg} \mathrm{ha}^{-1}$ in Ivory Coast and $510 \mathrm{~kg} \mathrm{ha}^{-1}$ in Ethiopia (Abubakar et al., 1998).

The decline in soil fertility is one of the primary constraints to agricultural production in sub-Saharan Africa (Sanchez and Jama, 2002; Nwite et al., 2011, 2013). In Africa, farmers apply fertilizer below the recommended rates (Cheruiyot et al., 2001). This along with poor agricultural practices has led to soil nutrient depletion (Smaling et al., 1993). As is the case in other regions in Africa, local farmers use inadequate nutrient inputs and inappropriate quality, which in the end prove to be very costly (Palm, 1997). A consequence of this trend is a deeply unbalanced soil nutrient composition that ultimately leads to a reduction in crop yield potential (Tonfack et al., 2009). Nutrients, when in adequate quantity, increases fruit quality, fruit size, colour, and fruit taste (Azad, 2000).

Organo-mineral fertilizer is a fertilizer in which organic wastes are fortified with inorganic nitrogen and/or phosphorus. These fertilizers are made up of organic materials complemented with inorganic minerals for fast action. The organic materials act as added enrichment for the humus content of the soil (Iren et al., 2017). Combine application of organic manure and mineral fertilizers buffer the soil against undesirable acidification and increasing the availability of nutrients (Iren et al 2014; 2016). The blending of organic manure with mineral fertilizer can help to increase the productivity of crops by reducing nutrient losses via leaching and erosion. The complementary application of organic and inorganic fertilizers to arable soil has been viewed as excellent way to have safe environment, recycle nutrients and organic matter that can support crop production and improve soil quality (Iren et al 2013; 2014). The single application of either organic or inorganic fertilizers in recent years have not really met the expected impact in boasting crop yield to cope with the challenges of food insecurity hence, integrated nutrient supply has been advocated by the Food and Agricultural Organization of the United Nation (Shiyam et al., 2011; Osundare et al., 2015). Kogi State is one of the major Sesame producing areas in Nigeria but not much has been done on plant population density and organo-mineral fertilizer rates on growth and yield of Sesame. Therefore, the objective of this study was to evaluate the influence of plant population density and organo-mineral fertilizer rates on the performance of sesame in Kabba, Kogi State, Nigeria.

\section{MATERIALS AND METHODS}

\section{Site Description}

The experiment was carried out in 2016 and 2017 seasons at the research site of agronomy section, Kabba College of Agriculture, Kabba. The site is located at latitude of $7.8231^{\circ} \mathrm{N}$ and longitude $6.0732^{\circ} \mathrm{E}$ and $400 \mathrm{~m}$ above sea level, in Southern Guinea Savanna Zone of Nigeria. Themonoidal rainfall spans April to November with peak in June and dry season extends from December to March. The mean annual rainfall is $1570 \mathrm{~mm}$ per annum with an annual temperature range of $18-32^{\circ} \mathrm{C}$. The mean relative humidity is $60 \%$.

\section{Land Preparation and Experimental Design}

The experimental field was ploughed, then double harrowed for proper pulverization and divided into plots $(5 \mathrm{~m} \times 4 \mathrm{~m})$. Before planting, 10 representative soil samples were randomly taken with the use of soil auger at different parts of the field. These were thoroughly mixed together to form a composite soil sample. It was air dried, sieved through a 2-mm sieve and used for the determination of bulk density and particle size as described by Carter (1993). Total porosity was calculated from the values of bulk density and particle density. Organic matter was determined by the Walkley and Black's dichromate wet oxidation method (Nelson and Sommers, 1982). Total N was determined by Micro-Kjeldahl digestion method. Available P was determined by Bray-1 extraction followed by Molybdenum blue colorimetric (Bray and Kurtz, 1945). The exchangeable bases $\left(\mathrm{K}^{+}, \mathrm{Ca}^{2+}\right.$ and $\left.\mathrm{Mg}^{2+}\right)$ were extracted by Ethylene Diamine Tetra Acetic Acid (EDTA) titration method (Jackson, 1962). Soil pH was determined in 1:2 soil-water ratio using digital electronic $\mathrm{pH}$ meter.

The experiment was a split plot laid out in a Randomized Complete Block Design (RCBD) with three replications. The main plot treatment was three plant population density $(\mathrm{P} 1=111,111 ; \mathrm{P} 2=83,333$ and P3 $=66,667$ plants $\mathrm{ha}^{-1}$ ) and the sub-plot treatment was four organo-mineral fertilizer rates $\left(\mathrm{F} 0=0, \mathrm{~F} 1=500, \mathrm{~F} 2=1000, \mathrm{~F} 3=1500 \mathrm{~kg} \mathrm{ha}^{-1}\right)$. The commercial organ-mineral fertilizer used was sourced from organo-mineral fertilizer plant at University of Ibadan. Seeds were sown using the drilling method and later thinned down to one seedling per stand. Weeds were manually controlled at 4, 7 and 10 weeks after sowing.

Data were collected on growth/morphological characters (plant height, number of leaves, number of branches) and yield components (number of capsules per plant, 1000 seed weight), and yield. Plant height was obtained at 4, 6, 8, and 10 weeks after sowing using measuring tape from the ground to the apex of the plant, number of leaves per plant were counted at 6 and 8 weeks after sowing and the average recorded for each year. Number of branches was counted in 2016 and 2017 and the average recorded for each year, stem diameter was obtained at 6 and 8 weeks after sowing using Vernier caliper at $10 \mathrm{~cm}$ above ground, number of capsules per plant was obtained by counting, 1000 seed weight, and grain yield per land area $\left(\mathrm{t} \mathrm{ha}^{-1}\right)$. 


\section{Statistical analysis}

Data were subjected to analysis of variance (ANOVA) using the GenStat statistical package (GenStat, 2007). Means were separated using the Least Significant Difference (LSD) at 5\% level of probability.

\section{RESULTS}

Physical and Chemical Properties of the Experimental Soil and Proximate Analysis of Organo-mineral Used During the Experiment The physical and chemical properties of the soil before the experiment are presented in Table 1. The results indicated the soil to be sandy clay loam with $\mathrm{pH}$ 6.2. The bulk density was $1.41 \mathrm{~g} \mathrm{~cm}^{-3}$. The soils had total porosity of $42.5 \%$. The soil organic matter was $2.14 \%$; nitrogen and available phosphorus were $0.16 \%$ and $2.72 \mathrm{mg} \mathrm{kg}^{-1}$, respectively. The $\mathrm{K}^{+}, \mathrm{Ca}^{2+}$ and $\mathrm{Mg}^{2+}$ were $0.46,2.5$ and $2.54 \mathrm{cmol} \mathrm{kg}^{-1}$, respectively. The proximate composition of the organo-mineral fertilizer used shows high contents of nitrogen $(2.5 \%)$, phosphorus $\left(1.10 \mathrm{mg} \mathrm{kg}^{-1}\right)$ and potassium $\left(0.68 \mathrm{cmol} \mathrm{kg}^{-1}\right)$ (Table 2$)$.

Effect of Plant Population Density and OrganoMineral Fertilizer Rates on Plant Height

As shown in Table 3, plant population density and organo-mineral fertilizer rates had significant effect on plant height at 4, 6, 8 and 10 weeks after sowing (WAS). The result showed that sesame plant height decreased with increase in plant population density. Plant population density at P1 gave the tallest plant throughout the growth period with 18.2 and 18.2, 55.2 and 78.1, 114.9 and 119.7 and 143.8 and143.9, respectively. This was followed by P2 (16.7 and 16.7, 51.0 and 67.6, 114.5 and 114.5 and 141.6 and 142.7) while P3 produced the shortest plants of 16.7 and 15.7, 45.4 and 60.5, 100.5 and 100.5 and 137.8 and 1381, respectively. However, P1 and P2 values were significantly similar at 6 WAS in 2016 and also significantly similar at 8 and 10 WAS in 2016 and 2017. P1 and P2 values differ sat 4 WAS in 2016 and 2017 and also differ at 6 WAS in 2017. Although P3 recorded the least values of plant height throughout the sampling period, but P3 values were statistically similar to $\mathrm{P} 2$ values at 4 WAS in both years and 6 WAS in 2017.
Significant effect was observed in sesame height due to the different rates of organo-mineral fertilizer. The result indicates that the higher the rate of organo-mineral fertilizer, the taller the plants. Although control plot produced the tallest plants of 19.2 and 17.9, respectively at 4 WAS in both years. However, at 6, 8 and 10 WAS, plots with organomineral fertilizer recorded higher plant height compared to the control plot irrespective of the rate applied. Among the organo-mineral fertilizer plots, F3 produced the tallest plants with 53.0 and 53.1, 113.6 and 113.6 and 165.7 and169.7in 2016 and 2017, respectively followed by F2 (48.5 and 52.9, 110.9 and 110.8 and 151.6 and 153.6) while F1 recorded the least plants height with 50.9 and 50.9b, 110.9 and 110.9 and 145.4 and 146.6.

Effect of Plant Population Density and OrganoMineral Fertilizer Rates on Stem Diameter (cm) Effect of plant population density and fertilizer rates on stem diameter is shown in Table 4. Plant population density and organo-mineral fertilizer had no significant influence on stem diameter of sesame in 2016 and 2017.

Table 1: Soil properties as determined before the study

\begin{tabular}{ll}
\hline Properties & Values \\
\hline Sand $(\%)$ & 64.5 \\
Clay (\%) & 20.0 \\
Silt $(\%)$ & 15.5 \\
Soil texture & Sandy clay loam \\
Soil pH & 6.2 \\
Bulk density $\left(\mathrm{g} \mathrm{cm}^{-3}\right)$ & 1.41 \\
Total porosity $(\%)$ & 42.5 \\
Organic matter $(\%)$ & 2.14 \\
Total N $(\%)$ & 0.16 \\
Available P $\left(\mathrm{mg} \mathrm{kg}^{-1}\right)$ & 2.72 \\
Exchangeable cation $\left(\mathrm{cmol} \mathrm{kg}^{-1}\right)$ & \\
$\mathrm{K}^{+}$ & 0.46 \\
$\mathrm{Ca}^{2+}$ & 2.5 \\
$\mathrm{Mg}^{2+}$ & 2.54 \\
\hline
\end{tabular}

Table 2: Proximate composition of the organo-mineral fertilizer used in the study

\begin{tabular}{ll}
\hline Properties & Values \\
\hline Nitrogen $(\%)$ & 2.58 \\
Phosphorus $\left(\mathrm{mg} \mathrm{kg}^{-1}\right)$ & 1.10 \\
Potassium $\left(\mathrm{cmol} \mathrm{kg}^{-1}\right)$ & 0.68 \\
Sodium $\left(\mathrm{cmol} \mathrm{kg}^{-1}\right)$ & 0.88 \\
Calcium $\left(\mathrm{cmol} \mathrm{kg}^{-1}\right)$ & 0.68 \\
\hline
\end{tabular}

Table 3: Effect of plant population density and organo-mineral fertilizer rates on plant height $(\mathrm{cm})$ of sesame

\begin{tabular}{|c|c|c|c|c|c|c|c|c|c|}
\hline \multirow{2}{*}{\multicolumn{2}{|c|}{ Treatment }} & \multicolumn{2}{|c|}{4 WAS } & \multicolumn{2}{|c|}{6 WAS } & \multicolumn{2}{|c|}{8 WAS } & \multicolumn{2}{|c|}{$10 \mathrm{WAS}$} \\
\hline & & 2016 & 2017 & 2016 & 2017 & 2016 & 2017 & 2016 & 2017 \\
\hline \multirow[t]{3}{*}{ Spacing $(\mathrm{P})$} & PI & $18.2^{\mathrm{a}}$ & $18.2^{\mathrm{a}}$ & $55.2^{\mathrm{a}}$ & $78.1^{\mathrm{a}}$ & $114.9^{\mathrm{a}}$ & $119.7^{\mathrm{a}}$ & $143.8^{\mathrm{a}}$ & $143.9^{\mathrm{a}}$ \\
\hline & P2 & $16.7^{\mathrm{b}}$ & $16.7^{\mathrm{b}}$ & $51.0^{\mathrm{a}}$ & $67.6^{\mathrm{b}}$ & $114.5^{\mathrm{a}}$ & $114.5^{\mathrm{a}}$ & $141.6^{\mathrm{a}}$ & $142.7^{\mathrm{a}}$ \\
\hline & P3 & $16.7^{\mathrm{b}}$ & $15.7^{\mathrm{b}}$ & $45.4^{\mathrm{b}}$ & $60.5^{\mathrm{b}}$ & $100.5^{\mathrm{b}}$ & $100.5^{\mathrm{b}}$ & $137.8^{\mathrm{b}}$ & $138.1^{\mathrm{b}}$ \\
\hline \multirow[t]{4}{*}{ Fertilizer $(\mathrm{F})$} & F0 & $19.2^{\mathrm{a}}$ & $17.9^{\mathrm{a}}$ & $49.6^{b}$ & $49.2^{\mathrm{c}}$ & $105.2^{\mathrm{b}}$ & $105.2^{\mathrm{b}}$ & $131.9^{\mathrm{c}}$ & $134.9^{\mathrm{c}}$ \\
\hline & F1 & $17.1^{\mathrm{ab}}$ & $16.2^{\mathrm{b}}$ & $50.9^{\mathrm{ab}}$ & $50.9^{\mathrm{bc}}$ & $110.9^{\mathrm{a}}$ & $110.9^{\mathrm{a}}$ & $145.4^{\mathrm{b}}$ & $146.6^{\mathrm{bc}}$ \\
\hline & F2 & $16.2^{\mathrm{b}}$ & $16.2^{\mathrm{b}}$ & $48.5^{\mathrm{b}}$ & $52.9^{\mathrm{ab}}$ & $110.9^{\mathrm{a}}$ & $110.8^{\mathrm{a}}$ & $151.6^{\mathrm{b}}$ & $153.6^{\mathrm{b}}$ \\
\hline & F3 & $17.3^{\mathrm{ab}}$ & $17.1^{\mathrm{ab}}$ & $53.0^{\mathrm{a}}$ & $53.1^{\mathrm{a}}$ & $113.6^{\mathrm{a}}$ & $113.6^{\mathrm{a}}$ & $165.7^{\mathrm{a}}$ & $169.7^{\mathrm{a}}$ \\
\hline Interaction & & ns & ns & ns & ns & ns & ns & ns & ns \\
\hline
\end{tabular}


Table 4: Effect of plant population density and organomineral fertilizer rates on stem diameter $(\mathrm{cm})$ of sesame

\begin{tabular}{|c|c|c|c|c|c|}
\hline \multirow{2}{*}{\multicolumn{2}{|c|}{ Treatment }} & \multicolumn{2}{|c|}{6 WAS } & \multicolumn{2}{|c|}{$8 \mathrm{WAS}$} \\
\hline & & 2016 & 2017 & 2016 & 2017 \\
\hline \multirow[t]{3}{*}{ Spacing $(\mathrm{P})$} & PI & $1.3^{\mathrm{a}}$ & $1.4^{\mathrm{a}}$ & $1.4^{\mathrm{a}}$ & $1.3^{\mathrm{a}}$ \\
\hline & P2 & $1.3^{\mathrm{a}}$ & $1.5^{\mathrm{a}}$ & $1.4^{\mathrm{a}}$ & $1.4^{\mathrm{a}}$ \\
\hline & P3 & $1.3^{\mathrm{a}}$ & $1.5^{\mathrm{a}}$ & $1.4^{\mathrm{a}}$ & $1.4^{\mathrm{a}}$ \\
\hline \multirow[t]{4}{*}{ Fertilizer $(\mathrm{F})$} & F0 & $1.2^{\mathrm{a}}$ & $1.3^{\mathrm{a}}$ & $1.2^{\mathrm{a}}$ & $1.3^{\mathrm{a}}$ \\
\hline & $\mathrm{F} 1$ & $1.3^{\mathrm{a}}$ & $1.4^{\mathrm{a}}$ & $1.3^{\mathrm{a}}$ & $1.4^{\mathrm{a}}$ \\
\hline & F2 & $1.3^{\mathrm{a}}$ & $1.5^{\mathrm{a}}$ & $1.3^{\mathrm{a}}$ & $1.5^{\mathrm{a}}$ \\
\hline & F3 & $1.4^{\mathrm{a}}$ & $1.5^{\mathrm{a}}$ & $1.4^{\mathrm{a}}$ & $1.5^{\mathrm{a}}$ \\
\hline \multicolumn{2}{|c|}{ Interaction (Sps vs. Fer) } & ns & $\mathrm{ns}$ & $\mathrm{ns}$ & ns \\
\hline \multicolumn{6}{|c|}{ 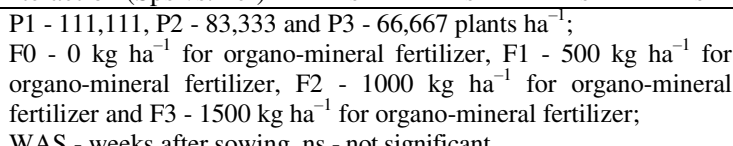 } \\
\hline
\end{tabular}

Effect of Plant Population Density and OrganoMineral Fertilizer Rates on Number of Leaves

Effect of plant population density on number of leaves of sesame is presented in Table 5. P1 gave the highest number of leaves (28.3 and 26.4) at 6 WAS in both years while the highest numbers of leaves (75.4 and 77.5) were recorded in $\mathrm{P} 2$ at 8 WAS in 2016 and 2017. Throughout the sampling period, P3 recorded the lowest number of leaves (22.5 and 20.4 and 67.5 and 69.5) and was inferior to P1 (75.4 and 77.5) and P2 (77.1 and 79.0) at 8 WAS in 2016 and 2017 experimental periods.

Number of leaves was significantly affected by organo-mineral fertilizer rate. Plots with F3 had the highest values of 29.0 and 86.6 in 2016 and 2017, respectively, and recorded significantly number than plots with F2 (77.1) in 2017 at 8 WAS.

Effect of Plant Population Density and OrganoMineral Fertilizer Rates on Number of Branches Effect of plant population density and organomineral fertilizer rates on number of branches of sesame in 2016 and 2017 are presented in Table 6. Plant population density significantly influenced number of branches of sesame. In 2016, the highest number of branches was recorded in plot with P3 (10.44) which was statistically similar to P2 (9.36). In 2017, P2 gave the highest number of branches (11.53) which was statistically different from the value obtained in P1 (9.64) and P3 (9.36). However, values of P1 (9.64) and P3 (9.36) were statistically similar in number of branches produced in 2017 cropping season.

Different rates of organo-mineral fertilizer used had significant effect on the number of branches produced in both years. The higher the rate of organo-mineral fertilizer applied, the better the number of branches produced. Numbers of branches produced were in the following order in both years, F3 (11.29 and 11.27) greater than F2 (10.38 and 10.38), while F2 (10.38 and 10.38) greater than F1 (9.55 and 9.56) and F1 (9.55 and 9.56) better than the control (9.51 and 9.51). Plots with F3 had the highest number of branches (11.29and 11.27) in 2016 and 2017, respectively.
Effect of Plant Population Density and OrganoMineral Fertilizer Rates on Yield and Yield Components of Sesame

The effect of plant population density and organomineral fertilizer rates on yield and yield component of Sesame are presented in Table 7. Significant difference was observed in the number of capsules and yield of Sesame due to the different plant population density used. However, no significant response was recorded on 1000 seed weight in 2016 and 2017 cropping seasons. Number of capsules per plant was highest in plots with P1 with 62.89 each in both years. Though, this was not significantly superior to number of capsules per plant in P2 with 62.80 each in 2016 and 2017. Number of capsules per plant in P1 (62.89 and 62.89) and P2 (62.80 and 62.80) were statistically higher than the plot with P3 (48.96 and 49.04) in both years. In 2016 and 2017, P1 produced higher yield (4.11 and 5.46) $\mathrm{t} \mathrm{ha}^{-1}$ compared to P2 (3.62 and 4.83) $\mathrm{t} \mathrm{ha}^{-1}$ while $\mathrm{P} 2$ also recorded yield $\mathrm{t} \mathrm{ha}^{-1}$ that was significantly higher than P3 (3.10 and 4.30). Table 7 also presented the effect of organo-mineral fertilizer rates on yield and yield components of Sesame. Plots treated with rate F2 gave the highest number of capsules (70.70 and $70.70)$ and also recorded the highest yield (4.10 and 5.54) $\mathrm{t} \mathrm{ha}^{-1}$ in 2016 and 2017 cropping seasons. Although number of capsules (70.70 and 70.70) and grain yield (4.10and 5.54) obtained in plots treated with F2 were higher but similar to number of capsules (64.86 and 64.86) and grain yield (3.76 and 5.02) produced with fertilizer rate F3. These were significantly better than plots with F1 (51.01 and 51.01 and 3.56 and 4.86) and the control (46.30 and 46.41 and 3.05 and 4.07) in both years. Control plot recorded the least value of number of capsules and lowest grain yield of sesame. The yield of the control was similar to yield produced using rate $\mathrm{F} 1$.

Table 5: Effect of plant population density and organomineral fertilizer rates on number of leaves of sesame

\begin{tabular}{|c|c|c|c|c|c|}
\hline \multirow{2}{*}{\multicolumn{2}{|c|}{ Treatment }} & \multicolumn{2}{|c|}{6 WAS } & \multicolumn{2}{|c|}{8 WAS } \\
\hline & & 2016 & 2017 & 2016 & 2017 \\
\hline \multirow{3}{*}{ Spacing $(\mathrm{P})$} & $\overline{\mathrm{PI}}$ & $28.3^{\mathrm{a}}$ & $26.4^{\mathrm{a}}$ & $75.4^{\mathrm{a}}$ & $77.5^{\mathrm{a}}$ \\
\hline & $\mathrm{P} 2$ & $24.9^{\mathrm{b}}$ & $21.9^{\mathrm{b}}$ & $77.1^{\mathrm{a}}$ & $79.0^{\mathrm{a}}$ \\
\hline & P3 & $22.5^{\mathrm{b}}$ & $20.4^{\mathrm{b}}$ & $67.5^{\mathrm{b}}$ & $69.5^{\mathrm{b}}$ \\
\hline \multirow[t]{4}{*}{ Fertilizer (F) } & F0 & $80.1^{\mathrm{b}}$ & $24.8^{\mathrm{b}}$ & $26.0^{\mathrm{b}}$ & $64.5^{\mathrm{c}}$ \\
\hline & $\mathrm{F} 1$ & $69.1^{\mathrm{c}}$ & $23.1^{\mathrm{b}}$ & $23.7^{\mathrm{bc}}$ & $69.1^{\mathrm{c}}$ \\
\hline & $\mathrm{F} 2$ & $81.1^{\mathrm{ab}}$ & $22.0^{\mathrm{b}}$ & $22.0^{\mathrm{c}}$ & $77.1^{\mathrm{b}}$ \\
\hline & $\mathrm{F} 3$ & $86.5^{\mathrm{a}}$ & $30.6^{\mathrm{a}}$ & $29.0^{\mathrm{a}}$ & $86.6^{\mathrm{a}}$ \\
\hline \multicolumn{2}{|c|}{ Interaction (Sps vs. Fer) } & ns & ns & ns & $\mathrm{ns}$ \\
\hline
\end{tabular}

Abbreviations and explanations are as explained in Table 4

Table 6: Effect of plant population density and organomineral fertilizer rates on number of branches on sesame

\begin{tabular}{llcc}
\hline \multicolumn{2}{c}{ Treatment } & 2016 & 2017 \\
\hline Spacing (P) & PI & $8.3^{\mathrm{b}}$ & $9.6^{\mathrm{b}}$ \\
& P2 & $9.3^{\mathrm{ab}}$ & $11.5^{\mathrm{a}}$ \\
& P3 & $10.4^{\mathrm{a}}$ & $9.4^{\mathrm{b}}$ \\
Fertilizer (F) & F0 & $9.5^{\mathrm{c}}$ & $9.5^{\mathrm{b}}$ \\
& F1 & $9.6^{\mathrm{c}}$ & $9.6^{\mathrm{b}}$ \\
& F2 & $10.4^{\mathrm{b}}$ & $10.4^{\mathrm{ab}}$ \\
\multicolumn{6}{l}{ Interaction (Sps vs. Fer) } & $11.3^{\mathrm{a}}$ & $11.3_{\mathrm{a}}$ \\
\hline
\end{tabular}

Abbreviations and explanations are as explained in Table 4 
Table 7: Effect of plant population density and organo-mineral fertilizer rates on yield and yield component of sesame

\begin{tabular}{|c|c|c|c|c|c|c|c|}
\hline \multirow{2}{*}{\multicolumn{2}{|c|}{ Treatment }} & \multicolumn{2}{|c|}{ Number of capsules plant ${ }^{-1}$} & \multicolumn{2}{|c|}{1000 seeds weight $(\mathrm{g})$} & \multicolumn{2}{|c|}{ Sesame grain yield/land area $\left(\mathrm{t} \mathrm{ha}^{-1}\right)$} \\
\hline & & 2016 & 2017 & 2016 & 2017 & 2016 & 2017 \\
\hline \multirow[t]{3}{*}{ Spacing } & PI & $62.9^{\mathrm{a}}$ & $62.9^{\mathrm{a}}$ & $2.3^{\mathrm{a}}$ & $2.3^{\mathrm{a}}$ & $4.1^{\mathrm{a}}$ & $5.5^{\mathrm{a}}$ \\
\hline & $\mathrm{P} 2$ & $62.8^{\mathrm{a}}$ & $62.8^{\mathrm{a}}$ & $2.3^{\mathrm{a}}$ & $2.3^{\mathrm{a}}$ & $3.6^{\mathrm{b}}$ & $4.8^{\mathrm{b}}$ \\
\hline & P3 & $49.0^{\mathrm{b}}$ & $49.0^{\mathrm{b}}$ & $2.2^{\mathrm{a}}$ & $2.2^{\mathrm{a}}$ & $3.1^{\mathrm{c}}$ & $4.3^{\mathrm{c}}$ \\
\hline \multirow[t]{4}{*}{ Fertilizer } & F0 & $46.3^{\mathrm{b}}$ & $46.4^{\mathrm{b}}$ & $2.2^{\mathrm{a}}$ & $2.2^{\mathrm{a}}$ & $3.1^{\mathrm{c}}$ & $4.1^{\mathrm{b}}$ \\
\hline & F1 & $51.0^{\mathrm{b}}$ & $51.0^{\mathrm{b}}$ & $2.4^{\mathrm{a}}$ & $2.4^{\mathrm{a}}$ & $3.6^{\mathrm{b}}$ & $4.9^{\mathrm{ab}}$ \\
\hline & $\mathrm{F} 2$ & $70.7^{\mathrm{a}}$ & $70.7^{\mathrm{a}}$ & $2.3^{\mathrm{a}}$ & $2.3^{\mathrm{a}}$ & $4.1^{\mathrm{a}}$ & $5.5^{\mathrm{a}}$ \\
\hline & $\mathrm{F} 3$ & $64.9^{\mathrm{a}}$ & $64.9^{\mathrm{a}}$ & $2.3^{\mathrm{a}}$ & $2.3^{\mathrm{a}}$ & $3.8^{\mathrm{ab}}$ & $5.0^{\mathrm{a}}$ \\
\hline Interactiol & s vs. Fer) & $\mathrm{ns}$ & $\mathrm{ns}$ & ns & ns & $\mathrm{ns}$ & ns \\
\hline
\end{tabular}

\section{DISCUSSION}

Proximate Composition of the Organo-mineral Fertilizer Used in the Experiment

Residues from bio-energy processes may be a source of fertilizer and nutrient cycling in agriculture (Nwite et al., 2013). The organo-mineral fertilizer is high in nitrogen, phosphorus and potassium and is expected to improve the fertility of the soil and consequently the performance of the Sesame.

Effect of Plant Population Density and OrganoMineral Fertilizer Rates on Sesame Growth

Maximum, intermediate and minimum plant height occurred with $111,111,83,333$ and 66,667 plants ha ${ }^{-1}$, respectively. The result agrees with Maya et al. (1997) where plant height increased with closer spacing. Sevgi et al. (2011) also reported tallest soybean plants with a close $30-\mathrm{cm}$ spacing. The present data, however, contrast with the findings of Ahmed et al. (2005) in Pakistan that plant height of sesame increased with its population density.

Control plots (F0) produced the tallest plants at 4 WAS in both years. The better performance of the control plots could be attributed to the inherent soil nutrients. However, at 6 and 10 WAS, plots with organo-mineral fertilizer at 1000 and $1500 \mathrm{~kg} \mathrm{ha}^{-1}$ gave taller plants than control plots. This observation reflects increased nutrient supply due to the applied fertilizer leading to increased nutrients use efficiency of sesame as the crop aged. This result shows that growth and yield parameters in crop are increased with organic fertilizer (Ali et al., 2000).

The thinnest stem diameter was recorded in plots with 111,111 plants $\mathrm{ha}^{-1}$ at 4 and 6 WAS in both years. Wider plant population density produced thicker stems. The result is in line with the findings of Morrison et al. (1995) suggested that increase in plant density leads to increase in intra-specific competition by apical meristem for especially sunlight and hence thinner stem. The level of light, as well as the red and infra-red ratio, plays an important role in stem elongation.

Again, higher plant population density produced more leaves. This result contrasts with Lakew et al. (2018) showing highest number of leaves per plant in wider spacing. López-Bellido et al. (2003) note that as plant density increases competition between plants becomes more intense, affecting the growth, development and production of each plant. Number of leaves of sesame increased as the rates of organo-mineral fertilizer applied increased, understandably due to increased nutrient availability which stimulated sesame growth and development.

The results for number of branches corroborated Leach et al. (1999) who reported that crop grown at high population density had fewer branches per plant. This result indicates the role of inter-row spacing in determining the number of branches per plant. Caliskan et al. (2004) also reported more branches per plants at lower sesame plant densities. However, Levy et al. (1985) reported taller and more branched plants a lower densities. Osei Bonsu (1975) found that increase in plant population did not affect plant height but reduced the number of branches. More branching with wider spacing in the present study is attributed to less intra-plant competition for space, sunlight and nutrients and associated proper use of energy (Anonymous, 1991).

The addition of the different rates of organomineral fertilizer increased the height and number of leaves of sesame plants compared with the untreated control. Organo-mineral fertilizers are known to give vigorous development in crop plant which is usually expressed in plant length and numbers of leaves and branches (Ghoname and Shafeek, 2005; Olaniyi and Ojetayo, 2010; Adepoju et al., 2017).

Effect of Plant Population Density and OrganoMineral Fertilizer Rates on Yield and Yield Components of Sesame

Closer plant population density giving 111,111 plants ha ${ }^{-1}$ produced the highest number of capsules per plant. This result contrasts with earlier studies on sesame by Osei Bonsu (1975).

Sesame yield was highest in plot with 111,111 plants $\mathrm{ha}^{-1}$. The result supports the work of Ogundare and Attah (2013) who reported better yield of pepper with lowest inter-row spacing. Kafiriti and Deckers (2001) also reported maximum yield of sesame with close spacing of the crops. Adubasim et al. (2017) achieved highest tuber yield of sweet potato with closest plant spacing of $30 \mathrm{~cm}$ by $60 \mathrm{~cm}$. Similarly, Obalum et al. (2017) recorded higher leaf yield of fluted pumpkin with narrow than with wide spacing. The higher yield observed could be as a result of more number of plants due to reduced spacing used. 
Plots with organo-mineral fertilizer produced higher grain yield compared with the control. These effects of organo-mineral fertilizer on sesame grain yield could be attributed to its ability to restore soil quality (Brady and Weil, 1999). Organo-mineral fertilizer ensures balanced plant nutrition for enhanced growth and crop yield (Adeniyan and Ojeniyi, 2003; Ojeniyi et al., 2009). In the present, $1000 \mathrm{~kg} \mathrm{ha}^{-1}$ produced the highest yield. Above this rate, yield of sesame tended to decrease.

\section{CONCLUSION}

The result indicated that sesame with highest plant population density was better in terms of number of capsule per plant and seed yield. For effective use of land, population density of 111,111 plants ha ${ }^{-1}$ be adopted in the production of sesame. Maximum growth of sesame was achieved with $1500 \mathrm{~kg} \mathrm{ha}^{-1}$ of organo-mineral fertilizer. However, its grain yield was highest with $1000 \mathrm{~kg} \mathrm{ha}^{-1}$. This application rate is, therefore, recommended for sesame production in the study area and similar savanna environments.

\section{REFERENCES}

Abubakar S.S., Onyibe J.E. and Tologbonshein E.B. (1998). The role of extension, research and information dissemination in enhancing beniseed production and marketing for resource poor farmers. Proc. First Workshop on Beniseed held at the National Cereal Research Institute, Badeggi, Nigeria, March 3-5, 1998, pp. 86-89

Adeniyan O.N. and Ojeniyi S.O. (2003). Comparative effectiveness of different levels of poultry manure in the NPK fertilizer and residual soil fertility nutrient uptake and yield of maize. Moor J. Agric. Res., 4 (2), 191-197

Adepoju I.O., Olabiyi T.I., Akanbi W.B. and Adeyeye A.S. (2017). Effect of organic and organomineral fertilizers on growth and yield of okra in nematode infested soil of Ogbomoso North Local Government, Oyo State, Nigeria. Published in Scientific Papers Series Management, Economic Engineering in Agriculture and Rural Development, 17 (3), 11-16

Adubasim C.V., Law-Ogbomo K.E. and Obalum S.E. (2017). Sweet potato (Ipomoea batatas) growth and tuber yield as influenced by plant spacing on sandy loam in humid tropical environment. Agro-Science, $16(3), 46-50$

Ahmed R., Mahmoud T., Saleemand M.F. and Ahmed S. (2005). Comparative performance of two Sesame (Sesamum indicum L.) cultivars under different row spacing. Asian J. Plant Sci., 1 (5), 546-557

Alegbejo M.D., Iwo G.A., Abo M.E. and Idowu A.A. (2003). Sesame: a potential industrial and export oil seed crop in Nigeria. J. Sustainable Agric., 23 (1), 59-76

Al Barzinjy M., Stolen O., Christiansen J.L. and Jensen J.E. (1999). Relationship between plant density and yield of two spring cultivars of oilseed rape (Brassica napus L.). Acta Agric. Scand., Section B - Soil Plant Sci., 49, 129-133

Ali J., Bakht J., Shafi M., Khan S. and Shah W.A. (2000). Uptake of nitrogen as affected by various combinations of nitrogen and phosphorus. Asian $J$. Plant Sci., 1, 367-369
Anonymous (1991). Vegetables research and development in the 1990s-A strategic plan. AVRDC Publ., pp. 1-61

Azad A.K. (2000). Effects of Plant Spacing, Source of Nutrients and Mulching on Growth and Yield of Cabbage. M.Sc. Thesis, Department of Horticulture, Bangladesh Agriculture University, Mymensingh, pp. $15-40$

Babaji B.A., Haruna I.M. and Mukhtar A.A. (2005). Sesame (Sesamum indicum L.): An oil boom for Northern Nigeria. Paper presented at the National Conf. on Development of Agriculture in the Northern Nigeria, Jun. 29 - Jul. 2, Institute for Development Research, Ahmadu Bello University, Zaria

Babaji B.A., Ali R.I., Yahaya M.A., Mahdi M.A. and Sharifai A.I. (2006). Nitrogen and phosphorus nutrition of sesame (Sesamum indicum L.) at Samaru. Proc. $31^{\text {st }}$ Annual Conf. Soil Science Society of Nigeria, 13-17 Nov. 2006, Ahmadu Bello University Zaria, Nigeria, 329-336

Board J. (2001). Reduced lodging for soybean in low plant population is related to light quality. Crop Sci., 41, 379-384

Brady N.C. and Weil R.R. (1999). The Nature and Properties of Soil $\left(12^{\text {th }}\right.$ ed.). Pearson Educational Publishers, Delhi, 881 pp.

Bray R.H. and Kurtz L.T. (1945). Determination of total and available forms of phosphorus in soils. Soil Science, 59, 39-45

Caliskan S.C., Arslan M.A., Arioglu H.A. and Isler N.I. (2004). Effect of planting method and plant population on growth and yield of sesame (Sesamum indicum L.) in a Mediterranean type of environment. Asian J. Plant Sci., 3 (5), 610-613

Carter M.R. (1993). Soil Sampling and Methods of Analysis. Canadian Society of Soil Science. Lewis Publisher London, 823

Cheruiyot E.K., Mumera L.M., Nakhone L.N. and Mwonga S.M. (2001). Rotational effects of grain legumes on maize performance in the Rift Valley highlands of Kenya. African Crop Sci. J., 9, 667-676

Diepenbrock W. (2000). Yield analysis of winter oilseed rape: A review. Field Crops Res., 67, 35-49

Dudley T.S., W. James and A. Mccallum. (2000). Texas agricultural experimental station, college station. Prepared April 12, p. 125

GenStat (2007). Genstat for Windows Discovery. 3rd ed., Lawes Agricultural Trust, Rothamsted Experimental Station, UK

Ghoname A. and Shafeek M.R. (2005). Growth and productivity of sweet pepper (Capsicum annum L.) grown in plastic house as affected by organic, mineral and bio-N-fertilizers. J. Agron., 4 (4), 369-372

Iren O.B., John N.M. and Imuk E.A. (2013). Influence of rates of pig manure and NPK $(15: 15: 15)$ fertilizer on soil chemical properties and dry matter yield of fluted pumpkn (Telfairia occidentalis Hook F.). Nigerian J. Soil Environ. Res., 11, 55-59

Iren O.B., John N.M. and Imuk E.A. (2014). Effects of sole and combined applications of organic manures and urea on soil properties and yield of fluted pumpkin (Telfaria occidentalis Hook F.). Nigerian J. Soil Sci., 24 (1), 125-133

Iren O.B., Ijah C.J., Asawalam D.O., Osodeke V.E. (2016). Comparative effect of pig manure, urea fertilizer and their combinations on the performance of Amaranthus cruentus in a rainforest Ultisol, Nigeria. J. Agric. Sci. Practice, 1, 52-57 
Iren O.B., Ofem K.I. and Okon P. (2017). Soil nutrient status and yield of waterleaf (Talinum triangulare Jacq) as influenced by rates of organomineral fertilizer in a rainforest Ultisol, Nigeria. Int. J. Appl. Res., 3, 581-585

Iwo G.A., Idowu A.A. and Ochigbo A.A. (2002). Evaluation of sesame genotypes for yield stability and selection in Nigeria. Nigeria Agric. J., 33, 76-82

Jackson M.L. (1962). Soil chemical analysis. Prentice Hall, Englewood cliffs, New Jersey. pp. 1-498

Kafiriti E.M. and Deckers J. (2001). Sesame, in crop production in tropical Africa. In: R.H. Raw Mackers, (ed.), DGIC; Ministry of Foreign Affairs, External Trade \& International Cooperation's. Brussels, Belgium, 797-803

Lakew S., Dereje A. and Fenta A. (2018). Optimum inter-row spacing and seeding rate of sesame for harnessing the maximum productivity potential in the dry land area of Abergelle District, Northeast Ethiopia. Cogent Food and Agric., 4 (1), 1-16

Leach J.E., Stevenson H.J., Rainbow A.J. and Mullen L.A. (1999). Effects of high plant populations on the growth and yield of winter oilseed rape (Brassica napus). $J$. Agric. Sci., 132, 173-180

Levy A., Palevitch D. and Kleifeld J. (1985). Evaluation of sesame cultivars and cultural practices in Israel. Sesame and safflower: status and potential, FAO Plant Prod. Prot. Paper, (66), 70-73. Retrieved: http://www.worldcat.org/title/sesame-and-safflowerstatus-andpotentials-proceedings-of-expertconsultation/oclc/ 16923924

López-Bellido R.J., López-Bellido L., López-Bellido F. J. and Castillo J.E. (2003). Faba bean (Vicia faba L.) response to tillage and soil residual nitrogen in a continuous rotation with wheat (Triticum aestivum L.) under rainfed Mediterranean conditions. Agron. J., 95 (5), 1253-1261

Nelson D.W. and Sommers L.E. (1982). Total carbon, organic carbon and organic matter. In: A.L. Page, R.H. Milles and D.R. Keeney (eds.) Methods of Soil Analysis part 2, (539-580). ASA Madison, WI

Nwite J.C., Keke C.I., Obalum S.E., Essien J.B., Anaele M.U. and Igwe C.A. (2013). Organo-mineral amendment options for enhancing soil fertility and nutrient composition and yield of fluted pumpkin. Int. J. Vegetable Sci., 19 (2), 188-199

Nwite J.C., Igwe C.A. and Obalum S.E. (2011). The contributions of different ash sources to the improvement in properties of a degraded Ultisol and maize production in southeastern Nigeria. AmEurasian J. Sustain. Agr., 5, 34-41

Maya P., Natarajan S. and Thamburay S. (1997). Effect of spacing, $\mathrm{N}$ and $\mathrm{P}$ on the growth and yield of sweet pepper (Capsicum annum). Bull. Fac. Agric. Cairo University, 45, 413-431

Morrison W.H., Hamilton R.J. and Kaln C. (1995). Sunflower seed oil. In: R.J. Hamilton (ed.), Developments in Oils and Fats (51-132). Blackie Academic and Professional, Glasgow
Obalum S.E., Edeh I.G., Imoh O.N., et al. (2017). Agronomic evaluation of seedbed and mulching alternatives with plant spacing for dry-season fluted pumpkin in coarse-textured tropical soil. Food Energy Security, 6 (3), 113-122

Ogundare S.K. and Attah E.S. (2013). Effect of varying intra row spacing on the growth and yield of pepper in Kabba, Kogi State, Nigeria. J. Hort. Sci., 18, 49-52

Ojeniyi S.O., Makinde E.A. Odedina S.A. and Odedina J.N. (2009). Effects of organomineral and NPK fertilizers on nutritional quality of Amaranthus in Lagos, Nigeria. Nigerian J. Soil Sci., 19 (2), 129-134

Olaniyi J.O. and Ojetayo A.E. (2010). The effect of organomineral and inorganic fertilizers on the growth, fruit yield and quality of pepper (Capsicum frutescence). J. Anim. Plant Sci., 8 (3), 1070- 1076

Olowe V.I.O. and Busari L.D. (2003). Growth and grain yield of two sesame (Sesamum indicum L.) varieties as affected by row spacing in Southern Guinea savanna of Nigeria. Samaru J. Agric. Res., 19, 91-101

Osei Bonsu K. (1975). The effect of spacing and fertilizer application on the growth, yield and yield components of sesame (Sesamum indicum L.). Paper presented at the IV Africa Symposium on Horticultural Crops. p. 53

Osundare O.T., Fajinmi A.A., and Okonji C.J. (2015). Effects of organic and inorganic soil amendments on growth performance of plantain (Musa paradisiaca L.). Afr. J. Agric. Res. 10, 154-160. https://doi. org/10.5897/AJAR2014.8645

Palm C.A., Myers R.J.K. and Nandwa S.M. (1997). Combined use of organic and inorganic nutrient sources for soil fertility maintenance and replenishment. In: R.J. Buresh, P.A. Sanchez and F.G. Calhoun (eds.), Replenishing Soil Fertility in Africa (193-218). Madison, WI, USA: Soil Science Society of America (SSSA)

Sanchez P.A. and Jama B.A. (2002). Soil fertility replenishment takes off in east and southern Africa. In: B. Vanlauwe, N. Diels, N. Sanginga et al. (eds.), Integrated Nutrient Management in Sub-Saharan Africa: from Concept to Practice (pp. 26-43), CAB International, Wallingford, UK

Sevgi C., Mehmet A., Ilhan U., and Mehmet E.C. (2011). The effects of row spacing on yield and yield components of full season and double-cropped soybean. Turkey J. Agric., 31, 147-154

Shiyam J.O., Oko B.F.D., Obiefuna J.C., and Ofoh M.C. (2011). Optimizing the productivity of plantain/cocoyam mixture by mulching and fertilizer application. World J. Agric. Sci., 7 (5), 633-637

Smaling E.M.A., Stoovogel J.J. and Windmeijer P.N. (1993). Calculating soil nutrient balances at different scales. II. District scale. Fertilizer Res. 35, 237-250

Tonfack L.B., Bernadac A., Youmbi E., Mbouapouognigni V. P., Ngueguim M. and Akoa A. (2009). Impact of organic and inorganic fertilizers on tomato vigor, yield and fruit composition under tropical andosol soil conditions. Fruits, 64 (3), 167-177 